\title{
Influence of Harvesting Season on Morphological and Sensory Quality, Bioactive Compounds and Antioxidant Activity of Three Late-Season Orange Cultivars 'Barberina', 'Valencia Midknight' and 'Valencia Delta Seedless'
}

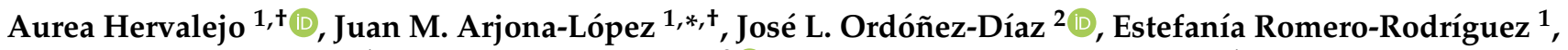 \\ Rocío Calero-Velázquez $^{1}$, José M. Moreno-Rojas ${ }^{2} \mathbb{D}$ and Francisco J. Arenas-Arenas ${ }^{1}$
}

check for

updates

Citation: Hervalejo, A.;

Arjona-López, J.M.; Ordóñez-Díaz,

J.L.; Romero-Rodríguez, E.;

Calero-Velázquez, R.; Moreno-Rojas,

J.M.; Arenas-Arenas, F.J. Influence of

Harvesting Season on Morphological

and Sensory Quality, Bioactive

Compounds and Antioxidant

Activity of Three Late-Season Orange

Cultivars 'Barberina', 'Valencia

Midknight' and 'Valencia Delta

Seedless'. Agronomy 2021, 11, 673.

https://doi.org/10.3390/

agronomy11040673

Academic Editors: Giorgia Liguori and Noemi Tel-Zur

Received: 24 February 2021

Accepted: 30 March 2021

Published: 2 April 2021

Publisher's Note: MDPI stays neutral with regard to jurisdictional claims in published maps and institutional affiliations.

Copyright: (c) 2021 by the authors Licensee MDPI, Basel, Switzerland. This article is an open access article distributed under the terms and conditions of the Creative Commons Attribution (CC BY) license (https:/ / creativecommons.org/licenses/by/ $4.0 /)$
1 Department of Agri-Food Engineering and Technology, Andalusian Institute of Agricultural and Fisheries Research and Training (IFAPA), "Las Torres" Center, Ctra. Sevilla-Cazalla de la Sierra km. 12.2, Alcalá del Río, 41200 Seville, Spain; aurea.hervalejo@juntadeandalucia.es (A.H.); estefania.romero.r@juntadeandalucia.es (E.R.-R.); rocio.calero@juntadeandalucia.es (R.C.-V.); fjose.arenas@juntadeandalucia.es (F.J.A.-A.)

2 Department of Food Science and Health, Andalusian Institute of Agricultural and Fisheries Research and Training (IFAPA), "Alameda del Obispo" Center, Avenida Menéndez-Pidal, SN, 14004 Córdoba, Spain; josel.ordonez@juntadeandalucia.es (J.L.O.-D.); josem.moreno.rojas@juntadeandalucia.es (J.M.M.-R.)

* Correspondence: juanm.arjona@juntadeandalucia.es

+ These authors contributed equally to this work.

Abstract: The genus Citrus amounts to one of the most relevant fruit crops in the world. This work assays overall fruit quality information in order to ascertain the optimal harvest timing of three late-season orange cultivars ('Barberina', 'Valencia Midknight' and 'Valencia Delta Seedless') during two consecutive growing seasons. Thus, morphological and physicochemical parameters, organic acids, polyphenolic content and antioxidant activity (ABTS and DPPH) were analyzed. 'Barberina' yielded the highest morphological (large and heavy fruits, albeit with lower fruit color index) and physicochemical (high juice content and intermediate but optimal acidity) fruit quality, with April providing the optimal harvest timing. By contrast, 'Valencia Delta Seedless' offered the smallest fruits, while 'Valencia Midknight' reported the lowest physicochemical juice quality (low juice content and earlier sensory depreciation). Nevertheless, both 'Valencia Delta Seedless' and 'Valencia Midknight' had higher functional quality than 'Barberina', which could be interesting for the industry in terms of obtaining higher added value products. Thus, 'Valencia Midknight' fruits recorded the highest organic acids concentration, especially in citric acid, while 'Valencia Delta Seedless' fruits showed the highest antioxidant activity and ascorbic acid concentration. In addition, while March-April emerged as the optimal harvest timing in terms of the highest organic acids concentration and antioxidant activity, it was February the optimal harvest timing for polyphenols content. Finally, the 2017/2018 growing season proposed better response of color index, density, polyphenols and antioxidants, but lower results of total organic acids.

Keywords: antioxidant activity; bioactive compounds; citrus; color index; HPLC; peel thickness; Rutaceae

\section{Introduction}

The genus Citrus (Rutaceae family) is one of the most important fruit crops worldwide, with oranges (Citrus sinensis L. Osb.) being the main citrus crop. Spain is Europe's largest orange producing country in the European Union, with a total production of more than 3.2 million tons in 2019 [1]. Production of this citrus fruit is aimed at two clearly differentiated markets: fresh fruit and juice [2]. In both cases, they require high levels of quality parameters $[3,4]$. 
Furthermore, the Citrus genus is comprised of a wide diversity of species and cultivars, including oranges, mandarins, lemons, grapefruits, citrons, limes, kumquats, and diverse hybrids. This extensive diversity yields high heterogeneous fruits parameters, such as morphological quality, physicochemical and nutritional compounds [5]. Internal and external orange fruit quality is another major influential factor, depending on type of cultivars [6,7], growing conditions [8,9], rootstock [10-12] or harvest season and fruit ripening [13].

On the other hand, peel and pulp ripening are not fully synchronized for orange fruits, with natural ripening of both tissues being a self-contained and independent process [14], which makes it seriously difficult to identify the optimal fruit harvest time. Hence, citrus farmers perform visual quality assessment of on-tree orange fruits based on external peel color, to determine the optimal harvest date $[8,9,15]$. This procedure is highly subjective due to its dependence on human evaluation; thus greater knowledge is required about fruit ripening and its effect on different quality parameters, primarily for citrus cultivars and citrus rootstocks $[6,7,16]$.

Late-season orange varieties can extend the fruit harvest period until the end of June in Spain, which makes this fruit available for consumers in markets. This group of oranges includes recent cultivars obtained, such as 'Barberina', 'Valencia Midknight', and 'Valencia Delta Seedless' [17].

Moreover, Carrizo citrange [Citrus sinensis L. Obs. $\times$ Poncirus trifoliata L. Raf.] is the most commonly used rootstock in Spanish citrus orchards [10]. Conversely, this prevailing rootstock can lead to chlorosis and salinity issues [18]. Hence, other citrus rootstocks, such as Forner-Alcaide no. 5 (substandard citrus rootstock), may allow more suitable adaptability to these abiotic problems as previously described [18,19].

Color is a major property in determining the degree of consumer acceptance [20], while the juice industry is demanding for citrus fruits with high juice yield and sugar content. The external and internal color of oranges, which is a major factor influencing consumer choices, is influenced by the carotenoids content [5,21]. Regardless of destination (fresh or juice), consumers perceive this food as a natural and healthy source of nutrients and vitamins.

In this sense, orange fruits contain a significant concentration of beneficial compounds for human health [22,23]. This fruit is a natural source of antioxidant and bioactive compounds, such as organic acids and phenolic compounds [24]. Citric acid is the main organic acid in oranges, followed by malic and ascorbic acids [25]. Furthermore, phenolic compounds of citrus fruits have been involved in the antioxidant complex in different studies [26-28]. Phenolic compounds of oranges include flavonoids and phenolic acids, with flavanones being the most important group of phenolic compounds in citrus [29]. Thus, the main flavanones in orange fruits, such as hesperetin, naringenin and their glycosylated derivatives, have a potent antioxidant activity [30]. Besides, these compounds can contribute to sensory properties, such as acidity, bitterness, astringency, flavor, etc. [18].

Therefore, this work was intended to determine morphological and physicochemical quality, bioactive compounds and antioxidant properties of three late-season orange cultivars ('Barberina', 'Valencia Midknight' and 'Valencia Delta Seedless') grafted onto a substandard citrus rootstock, and to evaluate those parameters during the harvest period (from February till May) over two consecutive growing seasons (2016/2017 and 2017/2018). Thus, offering the optimal harvest date for citrus industry and fresh consumption.

\section{Materials and Methods}

\subsection{Plant Material}

The experiments were carried out with three late-season orange cultivars ('Barberina', 'Valencia Midknight' and 'Valencia Delta Seedless') grafted onto the citrus rootstock FornerAlcaide no. 5 (FA5, 'Cleopatra' mandarin $\times$ Poncirus trifoliata L. Raf.; [31]), in a commercial orchard located in the municipality of Hornachuelos, Cordoba, Spain $\left(37^{\circ} 46^{\prime} 47.0^{\prime \prime} \mathrm{N}\right.$; $5^{\circ} 12^{\prime} 02.2^{\prime \prime} \mathrm{W}$ ) since 2011 . The orchard soil characteristics are clay-loam texture (40\% clay, 
$28 \%$ sand and $32 \%$ silt), $0.85 \%$ organic matter, an electrical conductivity (1:5 soil water extract) of $0.159 \mathrm{dS} / \mathrm{m}, 0.35 \%$ active $\mathrm{CaCO}_{3}$, and 8.2 of soil $\mathrm{pH}\left(25^{\circ} \mathrm{C} 1: 5\right)$. 'Barberina' is originated by spontaneous mutation of the 'Valencia' cultivar; its fruits are big in size, spherical and strong, seedless and of a high juice content. They are usually harvested from the end of April until the end of June. Of unknown origin, 'Valencia Midknight' cultivar fruits are medium-big size, with low presence of seeds and a high juice content that is optimal for juice industry. They can be harvested from March until the end of June. 'Valencia Delta Seedless', obtained by germination of one 'Valencia' seed, yields seedless fruits of a great quality. They can be harvested from mid-March until the end of June [17]. In addition, FA5 is a substandard citrus rootstock obtained by the breeding citrus rootstocks program of the Instituto Valenciano de Investigaciones Agrarias (IVIA) in Spain. It behaves well under salinity and limestone conditions (usual in the Mediterranean soils), as well as other abiotic factors, and it induces optimal fruit quality and high yield [10].

Crop management included typical local farmer practices, such as drip irrigation, chemical weed control, and annual hand pruning after fruit harvesting. Water requirements were calculated with the evapotranspiration values $\left(\mathrm{ET}_{0}\right)$ and citrus crop coefficient $\left(\mathrm{K}_{\mathrm{c}}\right)$ [32]. Crop fertilization was conducted by a fertigation system program following instructions reported by Quiñones et al. [33].

This study was performed over two consecutive growing seasons (2016/2017 and $2017 / 2018)$ and under Mediterranean climate conditions $\left(18.18^{\circ} \mathrm{C}\right.$ average temperature and $616.40 \mathrm{~mm}$ rainfall for $2016 / 2017$ season; $18.8^{\circ} \mathrm{C}$ average temperature and $454.60 \mathrm{~mm}$ rainfall for $2017 / 2018$ season). The experimental unit was three trees per each cultivar consisting of a randomized block with four replications spaced at $6 \mathrm{~m} \times 4 \mathrm{~m}$. Four fruit sampling dates were carried out for each growing season from February to May, with one sampling date per month, to establish the seasonal effect of the ripening stage on quality parameters. Each fruit sample consisted of nine oranges collected from each cultivar, replication and sampling date. Morphological, physicochemical quality parameters and bioactive compounds were measured for both growing seasons, such as color, equatorial diameter, height, juice content, density, titratable acidity, total soluble solids, maturity index, firmness, organic acid profile, antioxidant activity, and total phenolic content.

\subsection{Morphological Parameters}

Color Index was measured for each orange fruit with a Minolta colorimeter (Konica Minolta, CR-300, Minolta Corporation Ltd., Osaka, Japan), with the fruit being checked at three points around the equatorial plane. Using Hunter parameters, Color Index (C.I.) was determined as C.I. $=a^{*} \times 100 /\left(L^{*} \times b^{*}\right)$, where " $L^{* \prime}$ denotes lightness and " $a^{* \prime}$ and " $b^{* \prime}$ designate chromaticity coordinates [34]. Each fruit sample was weighted using a digital scale (COBOS precision, CB-3000C, L'Hospitalet de Llobregat, Barcelona, Spain), and average fruit weight was determined by dividing the total sample weight by the number of fruits in each fruit sample. Equatorial diameter (D; mm), height $(\mathrm{H} ; \mathrm{mm})$ and peel thickness (PT; mm) were obtained using an electronic digital slide gauge (Absolute digimatic caliper, Mitutoyo Corporation, Kawasaki, Japan).

\subsection{Physicochemical Parameters}

The juice was extracted from each fruit sample using an electric squeezer with a rotating head (Lomi ${ }^{\circledR}$, Modelo 5, Lorenzo Miguel, S.L., Madrid, Spain) and weighted with a digital scale; thus the juice to content ratio $(\% ; w / w)$ was determined by dividing the juice weight by the fruit sample weight. Juice density $\left(\mathrm{g} / \mathrm{cm}^{3}\right)$ was obtained using a calibrated Hydrometer $1000-1100$ at $20^{\circ} \mathrm{C}$ (Nahita, Madrid, Spain). First, the juice was tempered at the reference temperature indicated in the hydrometer $\left(20{ }^{\circ} \mathrm{C}\right)$. Next, the density parameter was determined by inserting this hydrometer into a $100 \mathrm{~mL}$ test tube that was filled up with juice, and by checking the point where the surface of the juice touches the stem of the hydrometer. Total soluble solids (TSS; ${ }^{\circ}$ Brix) were measured using a digital refractometer (Atago PR-101, Atago Corporation Ltd., Tokyo, Japan), and titratable 
acidity (TA; $\mathrm{g} / 100 \mathrm{~cm}^{3}$ ) was obtained by a $5 \mathrm{~mL}$ of juice titration with a $0.1 \mathrm{~N} \mathrm{NaOH}$ solution, and phenolphthalein as the indicator $[10,35]$. Maturity index (MI) was calculated as the TSS/TA ratio.

\subsection{Bioactive Compounds}

\subsubsection{Sample Preparation}

First, orange samples were peeled, fresh pulp was ground (Sammic Cutter SK-3, Gipuzkoa, Spain) and homogenized (Ultraturrax ${ }^{\circledR}$, Stauten, Germany). Aliquots of the homogenized pulp were used for different extraction methods. Samples were stored at $-80{ }^{\circ} \mathrm{C}$ until analysis.

\subsubsection{Organic Acids Analysis}

Organic acids extraction and chromatography analysis were performed following the method described by Ordóñez-Díaz et al. [36]. Organic acid extraction was carried out in dark and cold conditions, due to the high instability of organic acid extracts. Besides, the chromatography analysis was performed immediately after the extraction. The maximum wavelength of absorbance used for detection were $254 \mathrm{~nm}$ for ascorbic acid and $220 \mathrm{~nm}$ for the remaining organic acids. Quantification was carried out using calibration curves of pure organic acid standards in the range of $0.1-2500 \mathrm{mg} / \mathrm{L}$.

\subsection{Total Phenolic Content and Antioxidant Activity}

Total phenolic content and antioxidant activity analyses were carried out on hydrophilic extracts. Hydrophilic fractions were extracted using a mixed solution of methanol $(80 \%)$ and deionized water $(20 \%)$ acidified with $1 \%$ formic acid, following the method proposed by Moreno-Rojas et al. [37]. These analyses were performed using a Synergy HTX Multi-Mode Microplate Reader (BioTek Instruments, Winooski, VT, USA). The antioxidant activity was determined using two different methods: ABTS and DPPH assays.

\subsubsection{Total Phenolic Content}

Total phenolic content was determined by the Folin-Ciocalteu assay following the methodology of Slinkard and Singleton [38], with modifications of Cuevas et al. [39]. Total phenolic content was expressed as $\mathrm{mg}$ of gallic acid per $100 \mathrm{~g}$ of fresh weight (mg GAE/100 g FW).

\subsubsection{ABTS Assay}

Free radical scavenging activity was determined using the ABTS decoloration method [40] with brief modifications described by Madrona et al. [41]. The values were expressed as $\mathrm{mg}$ of Trolox equivalents per $100 \mathrm{~g}$ of fresh weight (mg TE/100 $\mathrm{g} \mathrm{FW).} \mathrm{Each} \mathrm{value} \mathrm{is} \mathrm{the}$ average of three technical replicates.

\subsubsection{DPPH Assay}

Free radical DPPH (1,1-diphenyl-2-picryl-hydrazyl) activity was determined in the hydrophilic extract following the methodology reported by Sánchez-Moreno et al. [42]. The values were expressed as mg of Trolox equivalents per $100 \mathrm{~g}$ of fresh weight (mg TE/100 g FW). Each value is the average of three technical replicates.

\subsection{Data Analysis}

Statistical analyses were performed with four replicates per year. The row values of each parameter were examined using the free software $\mathrm{R}$ version 4.0.3 [43] under a oneway variance analysis (ANOVA) and LSD-Fisher test $(p<0.05)[44]$, with the "agricolae" package [45]. 


\section{Results \\ 3.1. Morphological Parameters}

Overall, the fruit size (diameter and height) correlate directly proportionally with fruit ripening (sampling date), but without significance differences. Thus, the largest fruits were obtained for all of these orange cultivars in May. Comparing cultivars, 'Barberina' yielded larger fruits than the other two cultivars, with 'Valencia Delta Seedless' being the cultivar with the smallest fruit (Table 1). The fruit size was similar during 2016/2017 and 2017/2018 growing seasons.

Table 1. Mean of orange fruit morphological quality parameters \pm standard error (SE) of each cultivar ('Barberina', 'Valencia Midknight' and 'Valencia Delta Seedless'), each sampling date (February, March, April, May) and each growing season (2016/2017 and 2017/2018) tested using the same rootstock (Forner-Alcaide no. 5).

\begin{tabular}{|c|c|c|c|c|c|c|}
\hline Cultivar & $\mathrm{D} \pm \mathrm{SE}(\mathrm{mm})$ & $\mathbf{H} \pm \mathbf{S E}(\mathbf{m m})$ & $\mathrm{D} / \mathrm{H} \pm \mathrm{SE}$ & $\mathrm{PT} \pm \mathrm{SE}$ & $\mathrm{CI} \pm \mathrm{SE}$ & Weigh $(g) \pm$ SE \\
\hline 'Barberina' & $76.43 \pm 1.98 \mathrm{a}$ & $80.25 \pm 0.66 a$ & $0.95 \pm 0.02$ & $5.22 \pm 0.13 b$ & $10.37 \pm 0.10 b$ & $225.45 \pm 4.81 \mathrm{a}$ \\
\hline 'Valencia Midknight' & $70.91 \pm 0.57 b$ & $73.96 \pm 2.05 b$ & $0.99 \pm 0.01$ & $5.56 \pm 0.09 \mathrm{a}$ & $13.18 \pm 0.15 \mathrm{a}$ & $182.75 \pm 3.50 \mathrm{~b}$ \\
\hline $\begin{array}{c}\text { 'Valencia Delta Seedless' } \\
\quad p \text { value }\end{array}$ & $68.03 \pm \underset{* * *}{ \pm 0.66 b}$ & $69.53 \pm \underset{* * *}{0} 0.49 c$ & $\begin{array}{l}0.98 \pm 0.01 \\
\mathrm{~ns}\end{array}$ & $\underset{* *}{4.99 \pm 0.12 \mathrm{~b}}$ & $13.27 \underset{* * *}{ \pm 0.14} \mathrm{a}$ & $\underset{* * *}{163.95 \pm 3.75 c}$ \\
\hline \multicolumn{7}{|c|}{ Sampling date } \\
\hline February & $68.92 \pm 0.87$ & $73.89 \pm 2.57$ & $0.96 \pm 0.01$ & $4.91 \pm 0.14$ & $12.36 \pm 0.15 \mathrm{a}$ & $175.34 \pm 6.41 \mathrm{~b}$ \\
\hline March & $73.88 \pm 2.44$ & $74.74 \pm 1.07$ & $0.99 \pm 0.02$ & $5.56 \pm 0.10$ & $12.59 \pm 0.16 \mathrm{a}$ & $194.98 \pm 6.96 \mathrm{a}$ \\
\hline April & $71.55 \pm 0.82$ & $74.42 \pm 1.12$ & $0.96 \pm 0.01$ & $5.25 \pm 0.13$ & $11.76 \pm 0.16 b$ & $193.21 \pm 6.04 \mathrm{ab}$ \\
\hline May & $73.84 \pm 0.91$ & $75.98 \pm 1.46$ & $0.98 \pm 0.01$ & $5.33 \pm 0.21$ & NA & $207.97 \pm 10.16 \mathrm{a}$ \\
\hline$p$ value & ns & ns & ns & ns & $* *$ & ** \\
\hline \multicolumn{7}{|c|}{ Growing season } \\
\hline $2016 / 2017$ & $72.32 \pm 0.48$ & $73.45 \pm 0.73$ & $0.99 \pm 0.01 \mathrm{a}$ & $5.10 \pm 0.09 b$ & $11.55 \pm 0.14 b$ & $194.35 \pm 4.21$ \\
\hline $\begin{array}{l}2017 / 2018 \\
p \text { value }\end{array}$ & $\begin{array}{c}71.09 \pm 1.78 \\
\mathrm{~ns}\end{array}$ & $\begin{array}{c}76.09 \pm 1.77 \\
\mathrm{~ns}\end{array}$ & $\underset{*}{0.95 \pm 0.02 \mathrm{~b}}$ & $\begin{array}{c}5.46 \pm 0.11 \mathrm{a} \\
*\end{array}$ & $12.74 \underset{* * *}{ \pm} 0.11 \mathrm{a}$ & $\begin{array}{c}185.87 \pm 6.39 \\
n s\end{array}$ \\
\hline
\end{tabular}

Values with different letters are significantly different among cultivars, sampling date (month) or growing season, by LSD-Fisher test $(p<0.05)$. Significant level: ns $=$ not significant; ${ }^{*}=p<0.05 ;{ }^{* *}=p<0.001 ;{ }^{* * *}=p<0.0001$. NA: Not available data. D: Diameter; H: Height; D/H: Diameter/Height; PT: Peel thickness; CI: Color index.

The three cultivars yield fairly spherical fruits with a diameter/height ratio close to 1 (Table 1). 'Valencia Midknight' and 'Valencia Delta Seedless' showed more spherical fruits than 'Barberina', albeit without significant differences. The growing season had a major impact on shape orange fruits, reaching more spherical fruits (0.99) in 2016/2017 than in 2017/2018 (0.95). Otherwise, peel thickness was significantly different among cultivars. 'Valencia Midknight' showed the highest value of peel thickness, while 'Valencia Delta Seedless' yielded the lowest value of this parameter without significant differences compared with 'Barberina'. This parameter increased slightly during the ripening season without significant differences and was significantly higher during 2017/2018 than 2016/2017 (Table 1).

For color index, 'Barberina' produced the lowest value of this parameter significantly compared with the other two cultivars, while it was similar between 'Valencia Midknight' and Valencia Delta Seedless' without significant differences. This index increased slightly in March, but it significantly decreased in April. In addition, this parameter was higher during 2017/2018 than 2016/2017, with significant differences between both growing seasons (Table 1).

Furthermore, 'Barberina' produced the heaviest fruits where compared against the other two cultivars significantly, followed by 'Valencia Midknight' and 'Valencia Delta Seedless'. Fruit weight was higher at the end of the ripening season (May), albeit similar to the fruit weight reached in March, with the lowest value on the first month of this season (February). Both growing seasons (2016/2017 and 2017/2018) showed similar fruit weight values without significant differences, although this parameter was slightly higher during the 2016/2017 growing season (Table 1). 


\subsection{Physicochemical Parameters}

'Barberina' yielded orange fruits with the highest juice content with significant differences compared with the other two cultivars (Table 2), whereas 'Valencia Midknight' orange fruits recorded significantly the lowest juice. Juice content increased significantly in April and May compared with February and March. Additionally, juice content was higher during 2016/2017 than in 2017/2018, with significant differences (Table 2). For density, this parameter was very similar and stable during the whole ripening season for all the cultivars assayed without significant differences. Conversely, this parameter was significantly higher during 2017/2018 than in 2016/2017 (Table 2). Similarly, the amount of total soluble solids did not differ highly among cultivars, sampling dates and years assayed (Table 2); nevertheless, it increased over time. Conversely, titratable acidity was higher for 'Valencia Delta Seedless' than the two other cultivars with significant differences. This parameter decreased along fruit ripening (sampling dates), and it was the lowest value obtained in May, with significant differences. Otherwise, acidity was similar for both years assayed (2016/2017 and 2017/2018 growing seasons) (Table 2). Finally, maturity index was significantly higher for 'Valencia Midknight' compared with the two other cultivars. This index increased during fruit ripening (sampling dates) and was the highest value obtained in May with significant differences. However, this parameter was similar during both years assayed (Table 2).

Table 2. Mean of orange fruit physicochemical parameters \pm standard error (SE) of each cultivar ('Barberina', 'Valencia Midknight' and 'Valencia Delta Seedless'), each sampling date (February, March, April, May) and each growing season (2016/2017 and 2017/2018) tested using the same rootstock (Forner-Alcaide no. 5).

\begin{tabular}{|c|c|c|c|c|c|}
\hline Cultivar & Juice $(\%) \pm S E$ & Density $(g / c c) \pm S E$ & TSS $\left({ }^{\circ}\right.$ Brix $) \pm$ SE & $\mathrm{TA}\left(\mathrm{g} 100 / \mathrm{cm}^{3}\right) \pm \mathrm{SE}$ & $\mathrm{MI} \pm \mathrm{SE}$ \\
\hline 'Barberina' & $49.36 \pm 0.62 \mathrm{a}$ & $1.02 \pm 0.002$ & $10.38 \pm 0.10$ & $0.90 \pm 0.03 b$ & $11.87 \pm 0.38 b$ \\
\hline 'Valencia Midknight' & $46.03 \pm 0.43 c$ & $1.00 \pm 0.009$ & $10.71 \pm 0.27$ & $0.84 \pm 0.03 b$ & $13.86 \pm 0.77 \mathrm{a}$ \\
\hline $\begin{array}{c}\text { 'Valencia Delta Seedless' } \\
\quad p \text { value }\end{array}$ & $\underset{* * *}{47.77 \pm 0.46 b}$ & $\begin{array}{c}1.01 \pm 0.003 \\
\mathrm{~ns}\end{array}$ & $\begin{array}{c}10.58 \pm 0.08 \\
\mathrm{~ns}\end{array}$ & $0.99 \pm 0.03 \mathrm{a}$ & $10.92 \pm 0.34 \mathrm{~b}$ \\
\hline \multicolumn{6}{|c|}{ Sampling date } \\
\hline February & $47.19 \pm 0.53 b$ & $1.01 \pm 0.003$ & $10.31 \pm 0.10$ & $1.08 \pm 0.03 \mathrm{a}$ & $9.82 \pm 0.48 c$ \\
\hline March & $45.63 \pm 0.43 b$ & $1.01 \pm 0.004$ & $10.62 \pm 0.10$ & $0.87 \pm 0.03 \mathrm{~b}$ & $12.53 \pm 0.56 b$ \\
\hline April & $49.09 \pm 0.58 \mathrm{a}$ & $1.02 \pm 0.003$ & $10.56 \pm 0.30$ & $0.85 \pm 0.02 b c$ & $13.01 \pm 0.43 \mathrm{ab}$ \\
\hline $\begin{array}{l}\text { May } \\
p \text { value }\end{array}$ & $\underset{* * *}{50.19 \pm 0.77 a}$ & $\begin{array}{c}0.99 \pm 0.019 \\
\text { ns }\end{array}$ & $\begin{array}{c}10.90 \pm 0.16 \\
\mathrm{~ns}\end{array}$ & $0.76 \underset{* * *}{0.03 c}$ & $14.70 \pm \underset{* * *}{ \pm 0.94} \mathrm{a}$ \\
\hline \multicolumn{6}{|c|}{ Growing season } \\
\hline $2016 / 2017$ & $48.39 \pm 0.48 \mathrm{a}$ & $1.00 \pm 0.005 b$ & $10.40 \pm 0.16$ & $0.90 \pm 0.02$ & $12.21 \pm 0.43$ \\
\hline $2017 / 2018$ & $46.82 \pm 0.38 b$ & $1.03 \pm 0.001 \mathrm{a}$ & $10.76 \pm 0.09$ & $0.93 \pm 0.03$ & $12.17 \pm 0.52$ \\
\hline$p$ value & $*$ & $* * *$ & ns & ns & ns \\
\hline
\end{tabular}

Values with different letters are significantly different among cultivars, sampling date (month) or growing season, by LSD-Fisher test $(p<0.05)$. Significant level: $\mathrm{ns}=$ not significant; ${ }^{*}=p<0.05 ;{ }^{* *}=p<0.001 ;{ }^{* * *}=p<0.0001$. TSS: Total Soluble Solids; TA: Titratable Acidity; MI: Maturity index.

\subsection{Organic Acids}

Overall, citric acid is the main component of total organic acids in oranges. In particular, 'Valencia Midnight' showed the highest concentration of citric acid compared with other cultivars, followed by 'Barberina' and 'Valencia Delta Seedless' (Table 3). No significant differences were found for this compound in terms of sampling date and season (2016/2017 and 2017/2018). For malic acid, the second major component of total organic acids, no differences were observed among cultivars among growing seasons, but their concentration was influenced by the sampling date from February to May, with the highest concentration being reached in April (Table 3). Oxalic acid concentration was similar among different cultivars, but this compound achieved the highest values in May, albeit similar to March or April. Besides, the orange samples harvested on 2016/2017 season showed a higher oxalic acid content than samples harvested on $2017 / 2018$ season (Table 3). On the other 
hand, the ascorbic acid concentration was impacted by the cultivar, with 'Valencia Delta Seedless' samples being the ones with the higher concentration of ascorbic acid. No effects were observed on sampling date and year for this parameter (Table 3). In addition, the tartaric acid concentration was similar among the three cultivars. Regarding sampling date, the highest concentration of tartaric acid was found for the samples harvested in May. This parameter reported a higher value in 2016/2017 season than in 2017/2018 (Table 3). The concentration of succinic acid was similar for all cultivars, sampling date and growing seasons tested (Table 3). The lowest concentration of fumaric acid was obtained for the 'Valencia Midknight' cultivar. The concentration of fumaric acid decreased along sampling dates, and its content was significantly higher during 2016/2017 seasons (Table 3). The higher concentration of total organic acids was obtained for the 'Valencia Midknight' cultivar, with the lowest value found in February. No significant differences were found for the values between harvesting years (Table 3).

Table 3. Mean of orange organic acids concentration (mg/100 g FW) \pm standard error (SE) of each cultivar ('Barberina', 'Valencia Midknight' and 'Valencia Delta Seedless'), each sampling date (February, March, April, May), and each growing season (2016/2017 and 2017/2018) tested using the same rootstock (Forner-Alcaide no. 5).

\begin{tabular}{|c|c|c|c|c|c|c|c|c|}
\hline Cultivar & Citric Acid & Malic Acid & Oxalic Acid & $\begin{array}{l}\text { Ascorbic } \\
\text { Acid }\end{array}$ & Tartaric Acid & $\begin{array}{l}\text { Succinic } \\
\text { Acid }\end{array}$ & $\begin{array}{c}\text { Fumaric } \\
\text { Acid }\end{array}$ & $\begin{array}{l}\text { Total Organic } \\
\text { Acids }\end{array}$ \\
\hline 'Barberina' & $191.89 \pm 3.06 \mathrm{~b}$ & $139.30 \pm 8.14$ & $42.50 \pm 1.31$ & $23.96 \pm 0.63 b$ & $15.80 \pm 0.57$ & $9.28 \pm 0.30$ & $4.90 \pm 0.28 \mathrm{a}$ & $427.63 \pm 10.07 b$ \\
\hline $\begin{array}{l}\text { 'Valencia } \\
\text { Midknight' }\end{array}$ & $234.06 \pm 3.05 \mathrm{a}$ & $135.68 \pm 9.69$ & $44.65 \pm 1.02$ & $26.54 \pm 1.11 b$ & $17.44 \pm 0.65$ & $9.88 \pm 0.29$ & $4.09 \pm 0.24 b$ & $472.34 \pm 10.72 \mathrm{a}$ \\
\hline $\begin{array}{c}\text { 'Valencia Delta } \\
\text { Seedless' } \\
p \text { value }\end{array}$ & $\begin{array}{c}168.80 \pm 3.44 \mathrm{c} \\
* * *\end{array}$ & $\begin{array}{c}126.14 \pm 6.67 \\
\mathrm{~ns}\end{array}$ & $\begin{array}{c}44.06 \pm 1.08 \\
\mathrm{~ns}\end{array}$ & $\begin{array}{c}30.95 \pm 1.23 \mathrm{a} \\
* * *\end{array}$ & $\begin{array}{c}16.77 \pm 0.65 \\
\mathrm{~ns}\end{array}$ & $\begin{array}{c}9.15 \pm 0.34 \\
\text { ns }\end{array}$ & $\begin{array}{c}5.66 \pm 0.30 \mathrm{a} \\
* * *\end{array}$ & ${\underset{*}{* * *}}^{401.53 \pm 8.38 \mathrm{~b}}$ \\
\hline \multicolumn{9}{|c|}{ Sampling date } \\
\hline $\begin{array}{l}\text { February } \\
\text { March } \\
\text { April } \\
\text { May } \\
p \text { value }\end{array}$ & $\begin{array}{c}195.43 \pm 7.36 \\
199.10 \pm 7.55 \\
199.87 \pm 6.55 \\
198.98 \pm 8.92 \\
\text { ns }\end{array}$ & $\begin{array}{c}76.89 \pm 2.98 \mathrm{c} \\
146.38 \pm 3.91 \mathrm{~b} \\
172.10 \pm 5.82 \mathrm{a} \\
139.47 \underset{* * *}{ \pm} 4.81 \mathrm{~b}\end{array}$ & $\begin{array}{c}42.03 \pm 0.65 \mathrm{~b} \\
42.18 \pm 1.68 \mathrm{ab} \\
45.19 \pm 1.41 \mathrm{ab} \\
45.71 \pm 1.12 \mathrm{a}\end{array}$ & $\begin{array}{c}25.82 \pm 0.77 \\
26.83 \pm 1.02 \\
30.74 \pm 1.96 \\
25.29 \pm 1.06 \\
\text { ns }\end{array}$ & $\begin{array}{l}15.75 \pm 0.66 \mathrm{~b} \\
16.26 \pm 0.45 \mathrm{~b} \\
16.19 \pm 0.75 \mathrm{~b} \\
18.64 \pm 0.86 \mathrm{a}\end{array}$ & $\begin{array}{c}9.23 \pm 0.38 \\
10.08 \pm 0.21 \\
9.26 \pm 0.45 \\
9.17 \pm 0.35 \\
\text { ns }\end{array}$ & $\begin{array}{l}6.46 \pm 0.32 \mathrm{a} \\
5.03 \pm 0.29 \mathrm{~b} \\
4.20 \pm 0.17 \mathrm{c} \\
3.79 \underset{* * *}{ \pm 0.18 \mathrm{c}}\end{array}$ & $\begin{array}{l}371.62 \pm 6.78 \mathrm{c} \\
445.86 \pm 8.63 \mathrm{ab} \\
477.55 \pm 10.23 \mathrm{a} \\
441.05 \pm \underset{* * *}{ \pm} 11.91 \mathrm{~b}\end{array}$ \\
\hline \multicolumn{9}{|c|}{ Growing season } \\
\hline $\begin{array}{c}2016 / 2017 \\
2017 / 2018 \\
p \text { value }\end{array}$ & $\begin{array}{c}192.28 \pm 5.16 \\
204.56 \pm 5.25 \\
\text { ns }\end{array}$ & $\begin{array}{c}141.48 \pm 7.70 \\
125.56 \pm 5.26 \\
\text { ns }\end{array}$ & $\begin{array}{l}46.59 \pm 0.56 \mathrm{a} \\
40.84 \underset{* * *}{ \pm 0.99 \mathrm{~b}}\end{array}$ & $\begin{array}{c}26.41 \pm 0.63 \\
28.00 \pm 1.21 \\
\text { ns }\end{array}$ & $\begin{array}{l}17.81 \pm 0.54 \mathrm{a} \\
15.53 \underset{* *}{ \pm 0.41 \mathrm{~b}}\end{array}$ & $\begin{array}{c}9.62 \pm 0.22 \\
9.26 \pm 0.29 \\
\text { ns }\end{array}$ & $\begin{array}{c}5.32 \pm 0.25 \mathrm{a} \\
4.44 \underset{*}{*} 0.22 \mathrm{~b}\end{array}$ & $\begin{array}{c}439.50 \pm 11.17 \\
428.18 \pm 6.83 \\
\text { ns }\end{array}$ \\
\hline
\end{tabular}

Values with different letters are significantly different among cultivars, sampling date (month) or growing season, by LSD-Fisher test $(p<0.05)$. Significant level: $\mathrm{ns}=$ not significant; ${ }^{*}=p<0.05 ;{ }^{* *}=p<0.001 ;{ }^{* * *}=p<0.0001$.

\subsection{Total Phenolic Content}

The total phenolic content was similar for all the cultivars assayed. Regarding the sampling date, total phenolic content decreased slightly along the different months, with the lowest concentration being in May. Additionally, the concentration of these compounds was higher during the $2017 / 2018$ season than $2016 / 2017$ for the orange samples harvested (Table 4A).

\subsection{Antioxidant Activity}

Changes in antioxidant activity were observed in different orange cultivars with both antioxidant activity methods (Table 4). Thus 'Valencia Delta Seedless' had the highest values of antioxidant activity, showing significant differences with 'Valencia Midknight' (ABTS method) and 'Barberina' (ABTS and DPPH methods). Regarding the sampling date, antioxidant activity was similar for all the months tested, decreasing slightly in May. This reduction of antioxidant activity was only significant with the DPPH method. Concerning the growing season, the highest values of antioxidant activity were obtained for 2017/2018 (Table 4). 
Table 4. Mean of nutritional compounds of each cultivar ('Barberina', 'Valencia Midknight' and 'Valencia Delta Seedless'), each sampling date (February, March, April, May) and each growing season (2016/2017 and 2017/2018) tested using the same rootstock (Forner-Alcaide no. 5). (A) Mean of polyphenol content values (mg GA/100 g) \pm standard error (SE). (B) Mean of antioxidant activity ABTS assay values (mg TROLOX/100 g) \pm standard error (SE). (C) Mean of antioxidant activity DPPH assay values (mg TROLOX/100 g) \pm standard error (SE).

\begin{tabular}{|c|c|c|c|}
\hline Cultivar & A. Polyphenols & B. ABTS & C. DPPH \\
\hline 'Barberina' & $99.99 \pm 1.99$ & $94.75 \pm 2.07 b$ & $108.24 \pm 1.75 b$ \\
\hline 'Valencia Midknight' & $99.90 \pm 2.24$ & $99.68 \pm 2.37 b$ & $111.75 \pm 1.61 \mathrm{ab}$ \\
\hline $\begin{array}{l}\text { 'Valencia Delta Seedless' } \\
p \text { value }\end{array}$ & $\begin{array}{l}100.34 \pm 2.32 \\
\text { ns }\end{array}$ & ${ }_{* * *}^{109.35} \pm 2.81 \mathrm{a}$ & ${ }_{*}^{115.39} \pm 1.52 \mathrm{a}$ \\
\hline \multicolumn{4}{|l|}{ Sampling date } \\
\hline February & $105.13 \pm 2.20 \mathrm{a}$ & $102.82 \pm 3.57$ & $113.20 \pm 2.26 \mathrm{ab}$ \\
\hline March & $104.87 \pm 1.64 \mathrm{a}$ & $102.64 \pm 3.19$ & $114.54 \pm 1.80 \mathrm{a}$ \\
\hline April & $99.12 \pm 2.60 \mathrm{a}$ & $102.87 \pm 2.72$ & $110.92 \pm 1.84 \mathrm{ab}$ \\
\hline May & $90.68 \pm 1.90 \mathrm{~b}$ & $96.84 \pm 3.03$ & $108.52 \pm 1.81 \mathrm{~b}$ \\
\hline$p$ value & $* * *$ & ns & * \\
\hline \multicolumn{4}{|l|}{ Growing season } \\
\hline $2016 / 2017$ & $96.00 \pm 1.71 b$ & $92.90 \pm 1.54 b$ & $108.37 \pm 1.15 b$ \\
\hline $2017 / 2018$ & $104.28 \pm 1.55 \mathrm{a}$ & $110.05 \pm 1.84 \mathrm{a}$ & $115.41 \pm 1.39 \mathrm{a}$ \\
\hline$p$ value & $* * *$ & $* * *$ & $* * *$ \\
\hline
\end{tabular}

Values with different letters are significantly different among cultivars, sampling date or growing season, by LSD-Fisher test $(p<0.05)$. Significant level: $\mathrm{ns}=$ not significant; ${ }^{*}=p<0.05 ;{ }^{* *}=p<0.001 ;{ }^{* * *}=p<0.0001$.

\section{Discussion}

Transformation characteristics of citrus fruit ripening are highly related with fruit growth and color, sugar buildup and/or acid degradation [46]. The results of fruit size trends evolving into larger diameter are in accordance with previous studies $[47,48]$ and fulfill the minimum requirements of quality commercial standards for European Union Countries (R (EU) no. 543/2011 of European Commission, of 7 June 2011) [49] since the first sampling date (February). Optimal peel thickness is an important parameter of post-harvest quality, due to the fact that its fruits can be rougher or more sensitive if the peel is thick or thin, respectively [50]. Additionally, the response of the fruits to water stress is related to peel thickening, with an advanced maturation and juice fruit content reduction [51]. Peel coloration results suggest a greener peel color in April, with higher values for 'Valencia Midknight' and 'Valencia Delta Seedless' than 'Barberina', in line with a previous study for sweet oranges [50] and included in the maturity requirements of EU countries and the USA for oranges [52] since the first date sampling (February). This response could be influenced by different factors, such as the concentration of fruit carotenoids in different months [5,21,53,54], gibberellins [55], the effect of ethylene [56-58], carbohydrate availability $[55,59,60]$ and/or plant nutrition $[51,61,62]$.

Regarding morphological fruit quality, 'Barberina' showed the highest fruit diameter and weight, moderate peel thickness and fruit shape similar to 'Valencia Delta Seedless' and 'Valencia Midknight'. Considering that 'Barberina' orange fruit recorded the lowest peel color, fruit harvesting before April, at which time a greening of the fruit is recorded, would be of greater importance to this cultivar if the fruit were intended for the fresh market. Nevertheless, in April 'Barberina' fruits showed an optimal commercial color index.

Regarding sensory quality, these three cultivars have a remarkable juice content, specially 'Barberina'; additionally, they displayed considerable Total Soluble Solids (TSS) and Titratable Acidity (TA), similarly to results reported in prior studies [17,19]. Likewise, these juice content and maturity index values uphold and fulfill minimum requirements for commercial maturity and fruit taste ratios (R (EU) no. 543/2011 of European Commission, of 7 June 2011), which establish a minimum of $35 \%$ of juice content and 6.5 of maturity index for these orange cultivars [49]. Furthermore, maturity index is a major factor in 
deciding optimal harvest timing due to the fact that citruses are well-known non-climacteric fruits [5]; therefore, they need to complete full maturation on tree. April appears to be the most interesting harvest timing when optimal juice content is reached regardless of the solid soluble total-titratable acidity balance (sensory quality).

In this sense, 'Barberina' orange fruits showed the best physicochemical or sensory quality, recording the highest juice and solid soluble total contents, with a density similar to the two other cultivars. It showed an intermediate, but optimal titratable acidity, which induced an index maturity similar to 'Valencia Delta Seedless' and lower than 'Valencia Midknight'. Therefore, 'Valencia Midknight' displayed earlier internal fruit ripening, as a consequence of lower titratable acidity content.

This work evaluates seven organic acid compounds. Prior studies reported the importance of organic acids on citrus fruit nutritional quality [63,64], and concentration of these compounds can be used as a harvest timing indicator [52]. Thus, citric acid has a significant influence in fruit ripening as well as consumer acceptance. In line with previous studies into citrus fruits, citric acid was the predominant compound $[25,36,65,66]$, followed by malic, oxalic, ascorbic, tartaric, succinic and fumaric acid. Following a similar response than the preceding research, malic acid reported the second concentration of organic acids in orange fruits [66,67]. In addition, citrus fruits are well-recognized as an important natural source of Vitamin C (ascorbic + dehydroascorbic acid) [5], which is a major water-soluble antioxidant component $[63,68]$. Usually, ascorbic acid concentration is higher in oranges than other citrus fruits, such as grapefruits or mandarins, with few exceptions [69-71]. In our case, ascorbic acid ranks as the fourth major organic acid component, while fumaric acid is the lowest acid compound, which showed high dependency on the sampling date, as it was found in previous research [36]. On the contrary, other organic acids, such as malic and tartaric acids, increased during the growing season, reaching the maximum values in April (malic acid) or May (tartaric acid). This last trend was obtained for total acid organics, which reached their maximum value in April. Regarding cultivars, 'Valencia Midknight' recorded the highest citric acid and total organic acid concentrations; nevertheless 'Valencia Delta Seedless' yielded the highest values of ascorbic and fumaric acid concentrations.

In our results, the concentration of phenolic compounds is in the range of 87 to $110 \mathrm{mg}$ GA/100 $\mathrm{g}$ of fresh weight throughout the ripening season. These values agreed and not differ widely with the response obtained in recent studies for orange fruits reported by De Ancos et al. [72] and Ordoñez-Díaz et al. [36]. Nevertheless, it was noted that phenolic compounds concentration decreases during the fruit ripening season, recording a significant decline in May.

Antioxidant activity plays a major role as a nutritional factor of fruits [9]. Our results show similar values of antioxidant activity (ABTS and DPPH), which did not differ widely among the cultivars tested and sampling dates. However, 'Valencia Delta Seedless' displayed a higher antioxidant activity, and in all cases greater than 'Barberina'. Similarly, 'Valencia Delta Seedless' reported a higher concentration of ascorbic acid, which could partially contribute to the antioxidant activity of fruits $[36,73,74]$. The same behavior was reported for phenolic compounds, with 'Valencia Delta Seedless' showing the highest values, albeit without significant differences among cultivars. As for the ripening stage, the antioxidant activity remained stable throughout the trial.

\section{Conclusions}

This study reports the influence of different cultivars ('Barberina', 'Valencia Midknight' and 'Valencia Delta Seedless'), with the same citrus rootstock (Forner-Alcaide no. 5), ripening stage and harvest season on orange fruit quality parameters. The studied cultivars differ in fruit quality, specifying the harvest time for each one. Therefore, 'Barberina' and 'Valencia Delta Seedless' showed better preservation of fruit sensory quality on the tree, whereas 'Valencia Midknight' would require an earlier harvest timing.

Concerning the harvesting period for all cultivars, juice content, total soluble solids (TSS), and maturity index (MI) increased during the harvesting period, unlike titratable 
acidity (TA) and color index, with April being the more interesting harvest timing. While the color index decreased in April, it was commercially appropriated for all cultivars. On the other hand, organic acids concentration was higher from February to April, with April reporting the highest vitamin $\mathrm{C}$ concentration, while antioxidant activity was higher from March to April and phenolic compounds from February to March. Regarding the harvest season, parameters such as color index, density, polyphenols and antioxidants obtained a better response during 2017/2018, whereas the concentration of total organic acids were slightly higher in 2016/2017.

The three cultivars had different interests depending on the quality required by the market. Hence, 'Barberina' orange fruits showed the highest morphological and physicochemical quality. Nevertheless, both 'Valencia Delta Seedless', with the highest phenolic compounds, antioxidant activity and ascorbic acid concentration, and 'Valencia Midknight', with the highest total organic acids content, could generate an interest for the industry, in terms of yielding differentiated products given their greater nutritional value, an aspect highly that is highly valued by new consumers. Further research will be involved in the development and overall quality characterization from other new interesting cultivars and citrus rootstocks under Mediterranean growing conditions.

Author Contributions: Conceptualization, A.H., J.M.M.-R. and F.J.A.-A.; Methodology, A.H., J.L.O.D., E.R.-R., R.C.-V. and F.J.A.-A.; Software, A.H., J.M.A.-L., J.L.O.-D., and E.R.-R.; Validation, A.H., J.M.M.-R. and F.J.A.-A.; Formal Analysis, A.H., J.L.O.-D. and E.R.-R.; Investigation, A.H., J.L.O.D., E.R.-R., R.C.-V., J.M.M.-R. and F.J.A.-A.; Resources, A.H., J.L.O.-D., J.M.M.-R. and F.J.A.-A.; Data Curation, E.R.-R., J.M.A.-L., J.L.O.-D.; Writing-Original Draft Preparation, A.H., J.M.A.-L. and J.L.O.-D.; Writing-Review \& Editing, A.H., J.M.A.-L., J.L.O.-D., J.M.M.-R. and F.J.A.-A.; Supervision, J.M.M.-R. and F.J.A.-A.; Project Administration, J.M.M.-R. and F.J.A.-A. All authors have read and agreed to the published version of the manuscript.

Funding: This research was funded by the project "Network of Experimentation and Transfer in Andalusian Citrus (PR.TRA.TRA2019.001.001)", which was co-financed (80\%) by the European Regional Development Fund within the FEDER Operational Program of Andalusia 2014-2020.

Institutional Review Board Statement: Not applicable.

Informed Consent Statement: Not applicable.

Acknowledgments: The authors are grateful to "S.A.T. Cítricos de Moratalla" for providing the orchard location and its maintenance.

Conflicts of Interest: The authors declare no conflict of interest.

\section{References}

1. FAOSTAT. 2021. Available online: http://www.fao.org/faostat/es/\#data/QC (accessed on 11 February 2021).

2. USDA, United States Department of Agriculture, Foreing Agricultural Service. Citrus World Markets and Trade. 2020. Available online: https: / / www.fas.usda.gov / data/ citrus-world-markets-and-trade (accessed on 18 November 2020).

3. O'Neil, C.E.; Nicklas, T.A.; Rampersaud, G.C.; Fulgoni, V.L. 100\% Orange juice consumption is associated with better diet quality, improved nutrient adequacy, decreased risk for obesity, and improved biomarkers of health in adults: National Health and Nutrition Examination Survey, 2003-2006. Nutr. J. 2012, 11, 1-10. [CrossRef] [PubMed]

4. Peri, C. The universe of food quality. Food Qual. Prefer. 2006, 17, 3-8. [CrossRef]

5. Lado, J.; Gambetta, G.; Zacarias, L. Key determinants of citrus fruit quality: Metabolites and main changes during maturation. Sci. Hortic. (Amst.) 2018, 233, 238-248. [CrossRef]

6. Cardeñosa, V.; Barreira, J.C.M.; Barros, L.; Arenas-Arenas, F.J.; Moreno-Rojas, J.M.; Ferreira, I.C.F.R. Variety and harvesting season effects on antioxidant activity and vitamins content of citrus sinensis macfad. Molecules 2015, 20, 8287-8302. [CrossRef]

7. Gorinstein, S.; Martín-Belloso, O.; Park, Y.-S.; Haruenkit, R.; Lojek, A.; Ĉ́ž, M.; Caspi, A.; Libman, I.; Trakhtenberg, S. Comparison of some biochemical characteristics of different citrus fruits. Food Chem. 2001, 74, 309-315. [CrossRef]

8. Hervalejo, A.; Jiménez, M.; Trapero, S.; Lastres, J.M.; Martínez-Ferri, E. Respuesta al riego deficitario de 'Clementina de Nules' (Citrus clementina hort. ex tan.) injertado sobre diferentes patrones de cítricos. Levante Agrícola Rev. Int. Cítricos 2007, 387, 320-328.

9. Navarro, J.M.; Pérez-Pérez, J.G.; Romero, P.; Botía, P. Analysis of the changes in quality in mandarin fruit, produced by deficit irrigation treatments. Food Chem. 2010, 119, 1591-1596. [CrossRef]

10. Forner-Giner, M.; Alcaide, A.; Primo-Millo, E.; Forner, J.B. Performance of 'Navelina' orange on 14 rootstocks in Northern Valencia (Spain). Sci. Hortic. 2003, 98, 223-232. [CrossRef] 
11. Hervalejo, A.; Martínez-Ferri, E.; Salguero, A.; Arenas-Arenas, F.J. Growth, yield and fruit quality of 'Clemenules' grown on six rootstocks in the southern region of Spain during 2008/2009 season. In Proceedings of the 28th International Horticultural Congress (IHC), Lisbon, Portugal, 22-27 August 2010.

12. Legua, P.; Bellver, R.; Forner, J.; Forner-Giner, M.A. Plant growth, yield and fruit quality of 'Lane Late' navel orange on four citrus rootstocks. Span. J. Agric. Res. 2011, 9, 271-279. [CrossRef]

13. Xu, G.; Liu, D.; Chen, J.; Ye, X.; Ma, Y.; Shi, J. Juice components and antioxidant capacity of citrus varieties cultivated in China. Food Chem. 2008, 106, 545-551. [CrossRef]

14. Sozzi, G.O. Fisiología de maduración de los frutos de especies leñosas. In Árboles Frutales: Ecofisiología, Cultivo y Aprovechamiento; Sozzi, G.O., Ed.; Facultad de Agronomía, Universidad de Buenos Aires: Buenos Aires, Argentina, 2007; pp. $669-706$.

15. Agustí, M. Citricultura; Mundiprensa: Madrid, Spain, 2003; ISBN 84-8476-158-4.

16. Sánchez, M.-T.; la Haba, M.-J.; Serrano, I.; Pérez-Marín, D. Application of NIRS for nondestructive measurement of quality parameters in intact oranges during on-tree ripening and at harvest. Food Anal. Methods 2013, 6, 826-837. [CrossRef]

17. Romero-Rodríguez, E.; Hervalejo, A.; Castillo, C.I.; Arenas-Arenas, F.J. Caracterización de distintas variedades de cítricos para la industria en el Valle del Guadalquivir. Levante Agrícola Rev. Int. Cítricos 2014, 424, 264-271.

18. Legua, P.; Forner, J.B.; Hernández, F.; Forner-Giner, M.A. Physicochemical properties of orange juice from ten rootstocks using multivariate analysis. Sci. Hortic. 2013, 160, 268-273. [CrossRef]

19. Arenas-Arenas, F.J.; González-Chimeno, A.B.; Romero-Rodríguez, E.; Hervalejo, A. Characterization of different cultivars of citrus fruit for juice in the south of Spain. Citrus Res. Technol. 2017, 38, 1-9. [CrossRef]

20. Guzel, E.; Alizade, H.; Sinn, H. Optical properties of W. Navel and Hamlin oranges regarding mechanical harvesting and sorting. Agric. Mech. Asia Africa Lat. Am. 1994, 25, 57.

21. Alquézar, B.; Rodrigo, M.J.; Zacarías, L. Carotenoid biosynthesis and their regulation in citrus fruits. Tree For. Sci. Biotechnol. 2008, 2, 23-37.

22. Morton, L.W.; Caccetta, R.A.-A.; Puddey, I.B.; Croft, K.D. Chemistry and biological effects of dietary phenolic compounds: Relevance to cardiovascular disease. Clin. Exp. Pharmacol. Physiol. 2000, 27, 152-159. [CrossRef] [PubMed]

23. Pellegrini, N.; Serafini, M.; Colombi, B.; Del Rio, D.; Salvatore, S.; Bianchi, M.; Brighenti, F. Total antioxidant capacity of plant foods, beverages and oils consumed in Italy assessed by three different in vitro assays. J. Nutr. 2003, 133, 2812-2819. [CrossRef]

24. Sicari, V.; Dorato, G.; Giuffrè, A.M.; Rizzo, P.; Albunia, A.R. The effect of different packaging on physical and chemical properties of oranges during storage. J. Food Process. Preserv. 2017, 41, e13168. [CrossRef]

25. Kelebek, H.; Selli, S.; Canbas, A.; Cabaroglu, T. HPLC determination of organic acids, sugars, phenolic compositions and antioxidant capacity of orange juice and orange wine made from a Turkish cv. Kozan. Microchem. J. 2009, 91, 187-192. [CrossRef]

26. Gorinstein, S.; Cvikrová, M.; Machackova, I.; Haruenkit, R.; Park, Y.-S.; Jung, S.-T.; Yamamoto, K.; Ayala, A.L.M.; Katrich, E.; Trakhtenberg, S. Characterization of antioxidant compounds in Jaffa sweeties and white grapefruits. Food Chem. 2004, 84, 503-510. [CrossRef]

27. Rapisarda, P.; Tomaino, A.; Lo Cascio, R.; Bonina, F.; De Pasquale, A.; Saija, A. Antioxidant effectiveness as influenced by phenolic content of fresh orange juices. J. Agric. Food Chem. 1999, 47, 4718-4723. [CrossRef] [PubMed]

28. Wang, H.; Cao, G.; Prior, R.L. Total antioxidant capacity of fruits. J. Agric. Food Chem. 1996, 44, 701-705. [CrossRef]

29. Balasundram, N.; Sundram, K.; Samman, S. Phenolic compounds in plants and agri-industrial by-products: Antioxidant activity, occurrence, and potential uses. Food Chem. 2006, 99, 191-203. [CrossRef]

30. Di Majo, D.; Giammanco, M.; La Guardia, M.; Tripoli, E.; Giammanco, S.; Finotti, E. Flavanones in Citrus fruit: Structureantioxidant activity relationships. Food Res. Int. 2005, 38, 1161-1166. [CrossRef]

31. Forner, J.B.; Forner-Giner, M.A.; Alcaide, A. Forner-Alcaide 5 and Forner-Alcaide 13: Two new citrus rootstocks released in Spain. HortScience 2003, 38, 629-630. [CrossRef]

32. Doorenbos, J.; Pruitt, W. Crop Water Requirements; FAO Irrigation and Drainage Paper, No. 24; Food and Agriculture Organization of the United Nations: Rome, Italy, 1977.

33. Quiñones, A.; Martínez-Alcántara, B.; Primo-Millo, E.; Legaz, F. Fertilización de los cítricos en riego a goteo (I): N, P y K. Levante Agrícola Rev. Int. Cítricos 2007, 389, 380-385.

34. Jiménez, M.; Cuquerella, J.; Martínez, J. Determination of a color index for citrus fruit degreening. In Proceedings of the International Citrus Congress, 4th meeting of the International Society of Citriculture, Tokyo, Japan, 9-12 November 1981; Volume 2, pp. $750-753$.

35. Legua, P.; Bellver, R.; Forner, J.B.; Forner-Giner, M.A. Trifoliata hybrids rootstocks for 'Lane Late' navel orange in Spain. Sci. Agric. 2011, 68, 548-553. [CrossRef]

36. Ordóñez-Díaz, J.L.; Hervalejo, A.; Pereira-Caro, G.; Muñoz-Redondo, J.M.; Romero-Rodríguez, E.; Arenas-Arenas, F.J.; MorenoRojas, J.M. Effect of rootstock and harvesting period on the bioactive compounds and antioxidant activity of two orange cultivars ('Salustiana' and 'Sanguinelli') widely used in juice industry. Processes 2020, 8, 1212. [CrossRef]

37. Moreno-Rojas, J.M.; Moreno-Ortega, A.; Ordóñez, J.L.; Moreno-Rojas, R.; Pérez-Aparicio, J.; Pereira-Caro, G. Development and validation of UHPLC-HRMS methodology for the determination of flavonoids, amino acids and organosulfur compounds in black onion, a novel derived product from fresh shallot onions (Allium cepa var. aggregatum). LWT 2018, 97, 376-383. [CrossRef]

38. Slinkard, K.; Singleton, V.L. Total phenol analysis: Automation and comparison with manual methods. Am. J. Enol. Vitic. 1977, 28, 49-55. 
39. Cuevas, F.J.; Pradas, I.; Ruiz-Moreno, M.J.; Arroyo, F.T.; Perez-Romero, L.F.; Montenegro, J.C.; Moreno-Rojas, J.M. Effect of organic and conventional management on bio-functional quality of thirteen plum cultivars (Prunus salicina Lindl.). PLoS ONE 2015, 10, e0136596. [CrossRef]

40. Re, R.; Pellegrini, N.; Proteggente, A.; Pannala, A.; Yang, M.; Rice-Evans, C. Antioxidant activity applying an improved ABTS radical cation decolorization assay. Free Radic. Biol. Med. 1999, 26, 1231-1237. [CrossRef]

41. Madrona, A.; Pereira-Caro, G.; Bravo, L.; Mateos, R.; Espartero, J.L. Preparation and antioxidant activity of tyrosyl and homovanillyl ethers. Food Chem. 2011, 129, 1169-1178. [CrossRef] [PubMed]

42. Sánchez-Moreno, C.; Larrauri, J.A.; Saura-Calixto, F. A procedure to measure the antiradical efficiency of polyphenols. J. Sci. Food Agric. 1998, 76, 270-276. [CrossRef]

43. R Development Core Team. R: A Language and Environment for Statistical Computing; R Foundation for Statistical Computing, V.I. 3-900051-07-0; R Development Core Team: Vienna, Austria, 2020.

44. Steel, R.G.D.; Torrie, J.H. Principles and Procedures of Statistics: With Special Reference to the Biological Sciences; McGraw-Hill Book Company, Inc.: New York, NY, USA, 1960.

45. de Mendiburu, F. Statistical Procedures for Agricultural Research; Package "Agricolae", Version 1.4-4. Comprehensive R Archive Network; Institute for Statistics and Mathematics: Vienna, Austria, 2013.

46. Bain, J.M. Morphological, anatomical, and physiological changes in the developing fruit of the Valencia orange, Citrus sinensis (L.) Osbeck. Aust. J. Bot. 1958, 6, 1-23. [CrossRef]

47. Fattahi, J.; Hamidoghli, Y.; Fotouhi, R.; Ghasemnejad, M.; Bakhshi, D. Assessment of fruit quality and antioxidant activity of three citrus species during ripening. South Western J. Hortic. Biol. Environ. 2011, 2, 113-128.

48. Merino, C.; Hervalejo, A.; Salguero, A.; González, D.; Arenas-Arenas, F.J. Yield and fruit quality of two early maturing orange cultivars, 'Navelina' and 'Fukumoto', in Andalusia, Spain. Acta Hortic. 2015, 255-259. [CrossRef]

49. EUR-Lex-32011R0543-EN-EUR-Lex. 2020. Available online: https://eur-lex.europa.eu/legal-content/GA/TXT/?uri=CELEX\% 3A32011R0543 (accessed on 15 December 2020).

50. Hervalejo, A.; Suarez, M.; Moreno-Rojas, J.; Arenas-Arenas, F. Overall fruit quality of 'Lane Late' orange on sub-standard and semi-dwarfing rootstocks. J. Agric. Sci. Technol. 2020, 22, 235-246.

51. Koo, R.; Reese, R. Influence of Nitrogen, Potassium, and Irrigation on Citrus Fruit Quality. In Proceedings of the International Citrus Congress, 2nd meeting of the International Society of Citriculture, Orlando, FL, USA, 1-8 May 1977; Volume 1, pp. 34-38.

52. Lado, J.; Rodrigo, M.J.; Zacarías, L. Maturity indicators and citrus fruit quality. Stewart Postharvest Rev. 2014, 10, 1-6.

53. Ma, G.; Zhang, L.; Matsuta, A.; Matsutani, K.; Yamawaki, K.; Yahata, M.; Wahyudi, A.; Motohashi, R.; Kato, M. Enzymatic formation of -Citraurin from -Cryptoxanthin and Zeaxanthin by carotenoid cleavage Dioxygenase4 in the flavedo of citrus fruit. Plant Physiol. 2013, 163, 682-695. [CrossRef] [PubMed]

54. Rodrigo, M.J.; Alquézar, B.; Alós, E.; Medina, V.; Carmona, L.; Bruno, M.; Al-Babili, S.; Zacarías, L. A novel carotenoid cleavage activity involved in the biosynthesis of Citrus fruit-specific apocarotenoid pigments. J. Exp. Bot. 2013, 64, 4461-4478. [CrossRef]

55. Gambetta, G.; Martínez-Fuentes, A.; Bentancur, O.; Mesejo, C.; Reig, C.; Gravina, A.; Agustí, M. Hormonal and nutritional changes in the flavedo regulating rind color development in sweet orange [Citrus sinensis (L.) Osb.]. J. Plant Growth Regul. 2012, 31, 273-282. [CrossRef]

56. Purvis, A.C.; Barmore, C.R. Involvement of ethylene in chlorophyll degradation in peel of citrus fruits. Plant Physiol. 1981, 68, 854-856. [CrossRef]

57. Fujii, H.; Shimada, T.; Sugiyama, A.; Nishikawa, F.; Endo, T.; Nakano, M.; Ikoma, Y.; Shimizu, T.; Omura, M. Profiling ethyleneresponsive genes in mature mandarin fruit using a citrus 22K oligoarray. Plant Sci. 2007, 173, 340-348. [CrossRef]

58. Eilati, S.K.; Budowskj, P.; Monselise, S.P. Carotenoid changes in the 'Shamouti' orange peel during chloroplast-Chromoplast transformation on and off the tree. J. Exp. Bot. 1975, 26, 624-632. [CrossRef]

59. Huff, A. Sugar regulation of plastid interconversions in epicarp of citrus fruit. Plant Physiol. 1984, 76, 307-312. [CrossRef] [PubMed]

60. Fidelibus, M.W.; Koch, K.E.; Davies, F.S. Gibberellic acid alters sucrose, hexoses, and their gradients in peel tissues during color break delay in 'Hamlin' orange. J. Am. Soc. Hortic. Sci. 2008, 133, 760-767. [CrossRef]

61. Jones, W.W.; Embleton, T.W. The Visula Effect of Nitrogen Nutrition on Fruit Quality of Valencia Orange. Proc. Am. Soc. Hort. Sci. 1959, 73, 234-236.

62. Quiñones, A.; González, M.; Montaña, C.; Primo-Millo, E.; Legaz, F. Fate and uptake efficiency of 15N applied with different seasonal distributions in Citrus trees. In Proceedings of the International Citrus Congress, 10th meeting of the International Society of Citriculture, Agadir, Morocco, 15-20 February 2004; Volume 2, pp. 587-592.

63. Morales, J.; Salvador, A.; Besada, C.; Navarro, P.; Bermejo, A. Physico-chemical, sensorial and nutritional quality during the harvest season of 'Tango' mandarins grafted onto Carrizo Citrange and Forner-Alcaide no. 5. Food Chem. 2021, $339,127781$. [CrossRef] [PubMed]

64. Emmanouilidou, M.G.; Kyriacou, M.C. Rootstock-modulated yield performance, fruit maturation and phytochemical quality of 'Lane Late' and 'Delta' sweet orange. Sci. Hortic. 2017, 225, 112-121. [CrossRef]

65. Bermejo, A.; Cano, A. Analysis of nutritional constituents in twenty Citrus cultivars from the Mediterranean area at sifferent stages of ripening. Food Nutr. Sci. 2012, 03, 639-650. [CrossRef] 
66. Morales, J.; Bermejo, A.; Navarro, P.; Salvador, A. Rootstock effect on physico-chemical and nutritional quality of mandarin 'Clemenules' during the harvest season. Agronomy 2020, 10, 1350. [CrossRef]

67. Kelebek, H.; Selli, S. Determination of volatile, phenolic, organic acid and sugar components in a Turkish cv. Dortyol (Citrus sinensis L. Osbeck) orange juice: Determination of volatiles, phenolics, acids and sugars in Turkish orange juice. J. Sci. Food Agric. 2011, 91, 1855-1862. [CrossRef] [PubMed]

68. Kaur, C.; Kapoor, H.C. Antioxidants in fruits and vegetables-the millennium's health: Antioxidants in fruits and vegetables. Int. J. Food Sci. Technol. 2008, 36, 703-725. [CrossRef]

69. Alós, E.; Rodrigo, M.J.; Zacarías, L. Differential transcriptional regulation of l-ascorbic acid content in peel and pulp of citrus fruits during development and maturation. Planta 2014, 239, 1113-1128. [CrossRef]

70. Dhuique-Mayer, C.; Caris-Veyrat, C.; Ollitrault, P.; Curk, F.; Amiot, M.-J. Varietal and interspecific influence on micronutrient contents in Citrus from the Mediterranean area. J. Agric. Food Chem. 2005, 53, 2140-2145. [CrossRef] [PubMed]

71. Martí, N.; Mena, P.; Cánovas, J.A.; Micol, V.; Saura, D. Vitamin C and the role of Citrus juices as functional food. Nat. Prod. Commun. 2009, 4, 677-700. [CrossRef]

72. De Ancos, B.; Cilla, A.; Barberá, R.; Sánchez-Moreno, C.; Cano, M.P. Influence of orange cultivar and mandarin postharvest storage on polyphenols, ascorbic acid and antioxidant activity during gastrointestinal digestion. Food Chem. 2017, 225, 114-124. [CrossRef]

73. Kelebek, H.; Canbas, A.; Selli, S. Determination of phenolic composition and antioxidant capacity of blood orange juices obtained from cvs. Moro and Sanguinello (Citrus sinensis (L.) Osbeck) grown in Turkey. Food Chem. 2008, 107, 1710-1716. [CrossRef]

74. Jayaprakasha, G.K.; Patil, B.S. In vitro evaluation of the antioxidant activities in fruit extracts from citron and blood orange. Food Chem. 2007, 101, 410-418. [CrossRef] 